\title{
PERGESERAN PARADIGMA SISTEM INFORMASI MANAJEMEN
}

\author{
Devi Pramitha \\ e-mail : phe2_90@yahoo.co.id \\ FITK UIN Maulana Malik Ibrahim Malang
}

\begin{abstract}
Management Information Systems (MIS) is a field that began to develop since the 1960s. Although there is no single consensus, it is generally defined as a driver's license system that provides information used to support the operation, management, and decisionmaking in organization. Prainformasional in the community, the people in it using a rigid paradigm assisted by intuition, the basis used by them to select the types of information needed is often not obvious because it is colored by the subjective nature of perception. But then in today's modern society, in addition to the paradigm shift that uses a creative approach to merger, also using the scientific paradigm that enables the selection of information can be done quickly and accurately. In the world of education though, MIS become one of the important factors to improve services at the same time saving for education. With advances in the development of education in Indonesia, both from an administrative or technological aspect, the process of education services in Indonesia should be done effectively and efficiently. Therefore, to develop the quality of education needed some support facilities, where one of the supporting facilities is the application of information technology in the field of Management Information Systems
\end{abstract}

Keywords: Management Information System, Paradigm Shift, Education

\section{Abstrak}

Sistem Informasi Managemen (SIM) merupakan sebuah bidang yang mulai berkembang semenjak tahun 1960an. Walau tidak terdapat konsensus tunggal, secara umum SIM didefinisikan sebagai sistem yang menyediakan informasi yang digunakan untuk mendukung operasi, manajemen, serta pengambilan keputusan sebuah organisasi. Di lingkungan masyarakat prainformasional, orang-orang di dalamnya menggunakan paradigma secara kaku yang dibantu oleh intuisi, dasar yang digunakan oleh mereka untuk menyeleksi jenis-jenis informasi yang dibutuhkan sering tidak jelas karena diwarnai oleh persepsi yang sifatnya subjektif. Akan tetapi kemudian di masyarakat modern saat ini, disamping adanya pergeseran paradigma yang menggunakan pendekatan penggabungan yang kreatif, juga menggunakan paradigma ilmiah yang memungkinkan pemilihan informasi dapat dilakukan dengan cepat dan tepat. Dalam dunia pendidikan sekalipun, SIM menjadi salah satu faktor penting untuk meningkatkan pelayanan sekaligus penghematan bagi pendidikan. Dengan kemajuan perkembangan pendidikan di Indonesia, baik dari aspek administratif atau teknologi, maka proses pelayanan pendidikan di Indonesia harus dilakukan secara efektif dan efisien. Oleh karena itu, untuk mengembangkan mutu pendidikan dibutuhkan beberapa fasilitas pendukung, dimana salah satu fasilitas pendukung tersebut adalah aplikasi teknologi informasi dalam bidang Sistem Informasi Manajemen.

Kata Kunci: Sistem Informasi Manajemen, Pergeseran Paradigma, Pendidikan 


\section{Pendahuluan}

Saat ini jika kita mendengar istilah Sistem Informasi Manajemen (SIM), maka kita akan membayangkan suatu sistem komputer. Padahal sesungguhnya pengertian tentang SIM di dalam organisasi telah ada sebelum perangkat komputer diciptakan. Sistem Informasi Manajemen konvensional terkandung dalam pekerjaan-pekerjaan sistematis seperti pencatatan agenda, kearsipan, komunikasi di antara manajer-manajer organisasi, penyajian informasi untuk pengambilan keputusan, dan lain sebagainya (Sutabri, 2005). Akan tetapi dengan adanya komputer sebagai salah satu bentuk revolusi dalam teknologi informasi, pemrosesan data dapat dilakukan secara cepat bahkan mampu menyajikan informasi yang akurat, yang sekiranya jika dilakukan secara manual tanpa bantuan komputer memerlukan waktu yang cukup lama.

Sehingga pada umumnya, apabila kita sedang membicarakan tentang Sistem Informasi Manajemen (SIM), yang tergambar dalam pikiran kita adalah suatu sistem yang diciptakan untuk melaksanakan pengolahan data yang akan dimanfaatkan oleh suatu organisasi tersebut. Pemanfaatan data di sini dapat berarti penunjang pada tugas-tugas rutin, evaluasi terhadap prestasi organisasi, atau untuk pengambilan keputusan suatu organisasi. Tersedianya teknologi pengolahan data dengan komputer serta penggunaan komputer untuk menunjang SIM tidak dapat dihindari lagi, baik pada masa kini maupun di masa yang akan datang. Oleh karena itu Sistem Informasi Manajemen sangatlah penting, dan kecenderungan pengembangan SIM semakin lama semakin meningkat.

Abad 20 yang lalu sering disebut sebagai abad informasi karena dalam kenyataannya informasi sangat penting untuk kehidupan manusia, termasuk juga dalam kehidupan bisnis. Dengan informasi manusia dapat memperoleh apa saja yang telah terjadi pada lingkungannya bahkan di luar lingkungannya. Kemajuan alat komunikasi pada milenium ketiga semakin mempermudah perolehan informasi dari berbagai sumber untuk berbagai kepentingan terutama dalam berbagai pengambilan keputusan didalam perusahaan, itulah sebabnya sangat dirasakan pentingnya mengelola informasi secara terintegrasi pada setiap organisasi perusahaan.

Paradigma Sistem Informasi Manajemen pun mengalami pergeseran yang cukup signifikan hingga saat ini. Sebagai contoh, Badan Pengadilan di berbagai Negara telah banyak yang menggunakan sistem komputerisasi untuk mengumpulkan dan menyampaikan informasi yang penting atau relevan yang nantinya dapat digunakan untuk bahan pengambilan keputusan. Begitu pula halnya dengan SIM yang canggih telah dikembangkan bagi perusahaan listrik dan instansi-instansi lainnya di berbagai tempat. Dengan menggunakan sistem ini, maka penghitungan biaya pada setiap instalasi dapat diberikan dengan cepat (Syamsi, 2000). Secara ringkas, sebuah organisasi setidaknya paling sedikit akan terpengaruh oleh penerapan SIM, yang mana setiap waktunya akan terus mengalami pergeseran paradigm yang disesuaikan dengan kebutuhan organisasi tersebut.

\section{Pekembangan Sistem Informasi Manajemen}

Dewasa ini semakin sering terdengar ungkapan yang mengatakan bahwa dunia modern sudah memasuki "era informasi". Artinya semakin disadari oleh banyak pihak bahwa informasi merupakan sumber daya yang makin penting peranannya dalam kehidupan manusia, meskipun teknologi yang digunakannya mungkin tidak dikuasainya. "Kearifan konvensional" mengatakan bahwa suatu organisasi yang masih kecil tidak membutuhkan banyak informasi, dan untuk pengolahan datanya cukup dilakukan secara manual. Akan tetapi di era informasi saat ini "kearifan konvensional" tersebut sudah tidak relevan lagi karena adanya kemajuan yang sangat pesat dan banyaknya terobosan yang berkembang, 
seperti adanya sistem Informasi Manajemen (SIM) saat ini (Siagian, 2009). Pergeseran paradigma konvensional menjadi modern telah menyebabkan terjadinya perubahan yang cukup signifikan dalam pola pengambilan keputusan yang dilakukan oleh manajemen baik pada tingkat operasional (pelaksana teknis) maupun pimpinan pada semua jenjang. Perkembangan SIM juga telah menyebabkan perubahan-perubahan peran dari para manajer dalam pengambilan keputusan, mereka dituntut untuk selalu dapat memperoleh informasi yang paling akurat dan terkini yang dapat digunakannya dalam proses pengambilan keputusan. Mereka juga diharapkan dapat dengan lebih mudah untuk menganalisis kinerja para karyawannya secara konstan dan konsisten dengan pemanfaatan teknologi informasi yang tersedia.

Di era informasi saat ini, sistem informasi manajemen (SIM) adalah salah satu topik yang sangat penting untuk dibicarakan. Mengapa demikian? Karena SIM berkaitan dengan pengorganisasian suatu organisasi yang melibatkan tiga hal penting dalam organisasi, yaitu sumbersumber informasi, teknologi informasi dan orang-orang yang terdapat di dalamnya. Dalam buku Management Information System for the Information Age, Stephen Hagg, dkk (2004) mendefinisikan SIM sebagai berikut: Management Information System (MIS) deals with the planning for, development, management, and use of information technology tools to help people perform all tasks related to information processing and management. Dari definisi tersebut, kita dapat menemukan tiga kata kunci, yaitu sumber informasi, teknologi informasi, dan orang-orang (pelaku). Sehingga orang-orang atau para karyawan menggunakan teknologi informasi di saat mereka bekerja. Memang, jika kita tidak hidup di era informasi, teknologi informasi tidak menjadi penting seperti saat ini.

Perkembangan dalam bidang sistem informasi manajemen (SIM) yang sangat pesat dalam dua dekade terakhir sudah berhasil menciptakan banyak kemudahan dan manfaat pada dunia bisnis; dan bahkan SIM pada hampir semua bidang usaha modern sudah dipandang sebagai sebuah kebutuhan yang bersifat mutlak (necessity). Dewasa ini perusahanperusahaan di Indonesia sudah mulai memperkenalkan dan menggunakan sistem informasi manajemen di lingkungan usahanya. Dengan menggunakan sistem informasi manajemen (SIM) perusahaan mendapatkan kemudahan dalam proses pengambilan keputusan. Proses pengambilan keputusan bisa lebih cepat, tepat dan efisien sehingga dapat bersaing dengan para kompetitor (perusahaan) lain. Hal tersebut selaras dengan yang dikemukakan oleh Efrain Turban (1993) yang mengatakan bahwa, Sistem Informasi Manajemen adalah sistem formal berbasis computer untuk menyediakan informasi bagi pengambil keputusan dalam organisasi.

Sebuah organisasi pasti mengadakan transaksi-transaksi yang harus diolah agar bisa menjalankan kegiatannya sehari-hari Computer bermanfaat untuk tugas-tugas pengolahan data organisasi, akan tetapi sebuah sistem informasi manajemen melaksanakan pula tugas-tugas lain dan lebih daripada sekedar sistem pengolahan data. Misalnya sistem untuk menyajikan informasi bagi manajemen dan bagi pengambilan keputusan. SIM dapat digambarkan sebagai sebuah bangunan piramida di mana lapisan dasarnya terdiri dari informasi untuk pengolahan transaksi, penjelasan status, dan sebagainya; lapisan berikutnya terdiri dari sumber-sumber informasi dalam mendukung operasi manajemen sehari-hari; lapisan ketiga terdiri dari sumber daya sistem informasi untuk membantu perencanaan taktis dan pengambilan keputusan untuk pengendalian manajemen; dan lapisan puncak terdiri dari sumber daya informasi untuk mendukung perencanaan dan perumusan kebijakan oleh tingkat puncak manajemen. Berikut gambaran Sistem Informasi Manajemen dalam bentuk piramida di bawah ini: 


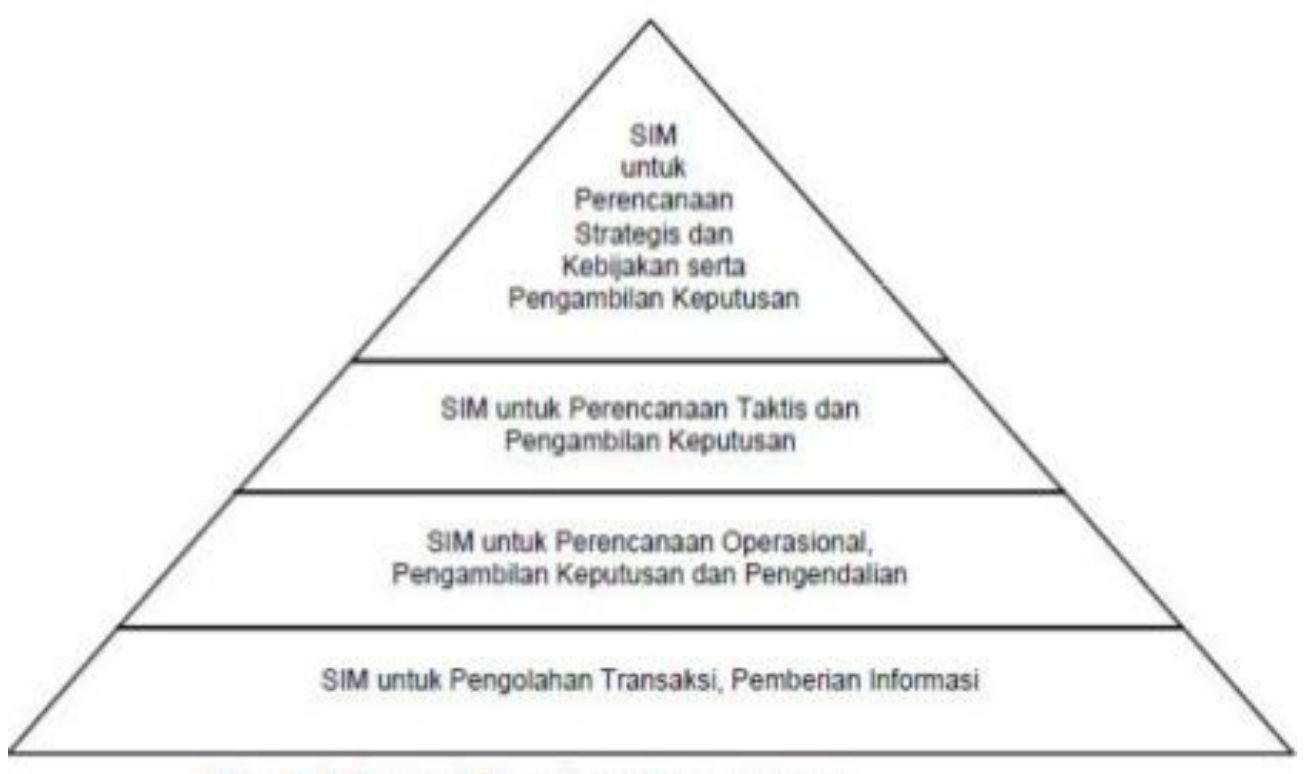

Sistem Informasi Manajemen (Robert V. H.)

Gambar: Sistem Informasi Manajemen (Diambil dari Robert V. Head, Management Information Systems; A Critical Appraisal, Datamation, Mei 1967, hlm. 23

Aspek-aspek tertentu pada SIM saat ini sudah banyak yang dikerjakan dengan bantuan alat pengolah data komputer. Pekerjaan SIM berkembang melalui empat proses sesuai dengan perkembangan alat pengolah data, yaitu: (1) dikerjakan secara manual; (2) dikerjakan dengan alat mesin manual; (3) dikerjakan dengan alat mesin elektrik; dan (4) dikerjakan dengan elektrik (komputer) (Amsyah, 2003). Sistem Informasi Manajemen hari ini umumnya dilakukan dengan gabungan keempat alat pengolah data tersebut, walaupun untuk pekerjaan pengolahan data umumnya sudah banyak dilakukan dengan bantuan komputer.

Sehingga istilah sistem informasi manajemen, yang umum dikenal orang, adalah sebuah sistem manusia/ mesin yang terpadu (integrated), untuk menyajikan informasi guna mendukung fungsi operasi, manajemen, dan pengambilan keputusan dalam sebuah organisasi. Di mana sistem ini menggunakan perangkat keras (hardware) dan perangkat lunak (software) computer, prosedur pedoman, model manajemen dan keputusan, serta sebuah data base (Davis, 1999).

\section{Implementasi Sistem Informasi Manajemen Dalam Dunia Pendidikan}

Sistem Informasi Manajemen (SIM) sekarang tidak lagi berkembang dalam bidang usaha saja, tapi sudah digunakan dalam berbagai bidang, terlebih dalam dunia pendidikan. Era baru dalam dunia pendidikan, yaitu diperkenalkannya reformasi pendidikan yang berkaitan erat dengan sistem informasi yang dibutuhkan dalam pengembangan dunia pendidikan. Konsep ini memiliki nuansa bagaimana dunia pendidikan berusaha menggunakan perangkat computer, yang dapat diaplikasikan sebagai sarana komunikasi untuk meningkatkan kinerja dunia pendidikan secara signifikan (Rochaety, dkk , 2006).

Lembaga pendidikan di Indonesia merupakan organisasi yang memiliki orientasi ganda (Multiple Oriented), yaitu organisasi yang berorientasi sosial dan orientasi bisnis. Di mana orientasi sosial pendidikan bertujuan meningkatkan kecerdasan bangsa sedangkan orientasi bisnis pendidikan bertujuan mempertahankan eksistensi yang mana proses operasionalnya harus memiliki dana yang cukup memadai. Oleh karena itu, SIM juga dikenal dengan ungkapan lainnya 
seperti: "Sistem Informasi", "Sistem Pemrosesan Informasi", "Sistem Informasi dan Pengambil Keputusan" (Davis dan Olson, 1984).

Sistem Informasi Manajemen (SIM) dalam dunia pendidikan idealnya adalah bagaimana para pengambil keputusan bidang pendidikan dapat dengan mudah mencari informasi sebagai bahan dalam proses pengambilan keputusan di bidang pendidikan. Misalnya, berapa jumlah suber daya manusia pendidikan yang dibutuhkan, jenis sekolah, tingkat sekolah, pelaksanaan kurikulum, perkembangan lembaga pendidikan lokal, regional, nasional, bahkan internasional untuk dapat memperbaiki kinerja dunia pendidikan masa lalu, masa kini, maupun masa yang akan datang. Sehingga Sistem Informasi Manajemen dalam dunia pendidikan adalah sistem yang didesain untuk kebutuhan manajemen dalam upaya mendukung fungsi-fungsi dan aktivitas manajemen pada suatu organisasi pendidikan. Maksud dilaksanakannya SIM dalam dunia pendidikan adalah sebagai pendukung kegiatan fungsi-fungsi manajemen; planning, organizing, actuating, dan controlling dalam rangka menunjang tercapainya sasaran dan tujuan fungsi-fungsi operasional dalam organisasi pendidikan.

Sebuah lembaga pendidikan dapat berjalan dan berkembang secara dinamis ketika kegiatan-kegiatan manajerial maupun operatif berfungsi dengan baik. Sebagai salah satu elemen manajemen, Sistem Informasi Manajemen (SIM) memiliki peran yang cukup vital dalam kekokohan lembaga pendidikan tersebut. Misalnya dalam pengambilan keputusan, tentunya lembaga pendidikan membutuhkan informasi yang akurat dan mudah diakses. Informasi ini nantinya berorientasi pada kepentingan manajemen organisasi, perencanaan dan operasionalisasinya berdasarkan arahan manjemen yang telah disusun sedemikian rupa untuk mencapai tujuan organisasi.

Perancangan atau penerapan SIM dalam dunia pendidikan bermula dari masalah yang muncul dari lembaga pendidikan. Masalah-masalah yang sering dihadapi oleh lembaga pendidikan sehingga membutuhkan SIM diantaranya adalah data pendaftaran siswa baru, data alumni atau lulusan, data siswa pindahan, pengelolaan keuangan, kegiatan proses pembelajaran, pengelolaan perpustakaan, administrasi kepegawaian yang meliputi data guru dan karyawan maupun data mutasi guru, kegiatan ekstra dan intra kurikuler siswa, hubungan dengan Dinas Pendidikan Kabupaten/ Kota dan Dinas Pendidikan Provinsi serta hubungan kemitraan dengan dunia usaha dan industry, dan masih banyak lagi permasalahan lainnya. Oleh karena itu dengan adanya SIM (Sistem Informasi Manajemen) maka manajemen pendidikan di sekolah dapat dilakukan dengan lebih mudah terkontrol.

Pada dasarnya setiap kendala atau masalah bisa dicarikan jalan keluarnya. Untuk mengatasi kendala atau masalah yang telah disebutkan di atas maka setidaknya bisa diselesaikan dengan beberapa cara sebagai berikut: pertama, pengelolaan sistem informasi akademik dimana pendaftaran siswa baru dapat dilakukan secara online melalui website, sehingga semua orang di seluruh penjuru daerah dapat melakukannya tanpa harus secara fisik datang ke sekolah yang bersangkutan. Kedua, sistem dokumentasi dan kearsipan yang tersimpan dalam format elektronik secara rapi dengan menggunakan perangkat aplikasi berbasis EDMS (Electronic Document Management System), sehingga data alumni atau lulusan maupun data siswa pindahan dapat tersimpan dengan rapi. Ketiga, Perpustakaan Digital yang di dalamnya berisikan buku-buku maupun jurnal ilmiah yang dapat diakses dari manapun dan kapanpun. Dan masih banyak lagi contoh implementasi Sistem Informasi Manajemen yang dapat mendukung proses pendidikan lebih efektif dan efisien.

\section{Kesimpulan}

Setiap organisasi
menjalankan alam
memerlukan informasi dalam pengambilan
keputusan. Informasi yang digunakan
dalam pengambilan keputusan adalah


merupakan suatu data yang diproses terlebih dahulu sehingga menghasilkan sebuah informasi dan proses ini dinamakan Sistem Informasi Manajemen. Konsep SIM membawa fungsi sistem informasi jauh di atas tingkat operasional dan menjadi sebuah sistem yang memberikan sumber daya informasi guna mendukung bidang-bidang keputusan dan perencanaan manajemen.

Sistem Informasi Manajemen (SIM) merupakan bidang yang harus dikembangkan oleh setiap organisasi yang ada di Indonesia. Perkembangan Sistem Informasi Manajemen (SIM) yang sangat cepat dan pesat ini, mengharuskan setiap organisasi dengan cepat pula untuk dapat beradaptasi dengan teknologi tersebut. Pemakai SIM memiliki jangkauan pada suatu data base yang luas dan pada sebuah bank model yang terdiri dari model analisis, pengolahan, pengambilan keputusan, perencanaan, dan lain sebagainya.

Dalam bidang pendidikan pun semakin perlu kehadiran SIM yang canggih. Hal ini guna menjawab tantangantantangan pendidikan dalam meningkatkan kualitas serta kuantitas pendidikan di Indonesia yang saat ini terbilang masih rendah bila dibandingkan dengan Negara-negara berkembang lainnya.

\section{Daftar Pustaka}

Amsyah, Zulkifli. 2003. Manajemen Sistem Informasi. Jakarta: PT. Gramedia Pustaka Utama.

Davis, Gordon B. and M. Olson. 1984. Management Information Systems. Tokyo: McGraw-Hill Kogakusha.

Davis, Gordon B. 1999. Kerangka Dasar Sistem Informasi Manajemen Bagian $I$, terj. Andreas S. Adiwardana. Jakarta: PT. Ikrar Mandiriabadi.

Hagg, Stephen, Maeve Cummings, and Donald J. McCubbrey. 2004. Managemenet Information Systems for the Information Age. New York: McGraw Hill Companies.

Rochaety, Eti, dkk. 2006. Sistem Informasi Manajemen Pendidikan. Jakarta: PT. Bumi Aksara.

Siagian, Sondang P. 2009. Sistem Informasi Manajemen. Jakarta: Bumi Aksara

Sutabri, Tata. 2005. Sistem Informasi Manajemen. Yogyakarta: Andi.

Syamsi, Ibnu. 2000. Pengambilan Keputusan dan Sistem Informasi. Jakarta: Bumi Aksara. 